\title{
Origanum syriacum ssp. sinaicum associated Growth Promoting Bacteria
}

\author{
Amr M. Mowafy ${ }^{1}$, Dalia A. Alraey ${ }^{2}$, Mohammed N. Omar ${ }^{2}$, Ahmed Elshobaky $^{1}$ \\ and Samia A. Haroun ${ }^{1}$ \\ ${ }^{1}$ Botany department, Faculty of Science, Mansoura University, Egypt \\ ${ }^{2}$ Soils, Water and Environment Research Institute, Agriculture Research Center, Giza, Egypt. \\ Running title: Origanum associated bacteria
}

\begin{abstract}
Plant growth promoting bacteria have several applications in agriculture as they could be used as bio-fertilizers and/or bio-control agents. Isolation, characterization and identification of Origanum syriacum ssp. sinaicum associated growth promoting bacteria was the aim of this study as Origanum is one of the most important wild endemic medicinal plants in Egypt. Out of 268 bacterial isolates whether rhizospheric or endophytic obtained firstly, the initial test for the production of gibberellic acid led to a reduction of this number to be 25. The nitrogenase activity was the second potential test by which 4 isolates were finally selected and tested for further plant growth promoting characteristics. $16 \mathrm{~S}$ rRNA analysis identified two of them to be Serratia sp. (Serratia SK3 and Serratia SK1a) and the other two to be Bacillus sp. (Bacillus SK1 and Bacillus SK2). The current investigation represents four local bacterial strains that could be used to enhance the growth of the commercially grown and widely used Origanum syriacum ssp. sinaicum in Egypt.
\end{abstract}

Keywords: Bacillus, Gibberellic acid, Origanum syriacum ssp. sinaicum, phosphate solubilization and Serratia

\section{Introduction}

Soil is often considered as a black box as it represents a suitable environment for a diverse and complicated community of bacteria, fungi, actinomycetes, protozoa, and algae. These microorganisms are always in direct or indirect contact with plant and the outcome might be in one of three forms; neutral, harmful, or beneficial relationship. The interaction between plant and these microorganisms may occur at the phyllosphere (above-ground portions of plant), rhizosphere (soil region directly influenced by root exudations) or endosphere (the internal transport system of the plant). Plant growth promoting bacteria might be termed as rhizospheric (PGPR), if they are inhabiting the root plane or it might be termed as plant growth promoting endophytic bacteria (PGPE) when they are present inside the plant tissues. The treatment of plants with plant growth promoting bacteria (either rhizospheric or endophytic bacteria) has been reported to increase the growth parameters such as germination rates, root growth, leaf area, yield, chlorophyll content, and shoot and root weights [1]. Plant growth promoting bacteria have several applications in agriculture as they might be used as bio-fertilizers and/or bio-control agents [2]. In agricultural applications, the advantage of inoculating seeds with endophytic PGPB is that, they will establish populations which will have a competitive advantage over organisms invading the rhizosphere [3]. Generally, plant growth promoting bacteria may stimulate the growth either directly by supplying the plant with fixed nitrogen, soluble phosphate, phytohormones, and the 1aminocyclopropane-1-carboxylate (ACC) deaminase activity [4-6] and/or indirectly by preventing phytopathogens from attacking the plant $[7,8]$. One of the most important wild endemic medicinal plants in Egypt is Origanum syriacum subsp. sinaicum (Boiss.) Greuter\&Burdet [9] which is a rare species [10] endemic to Sinai Peninsula in Egypt [11]. The over exploitation in addition to habitat loss, deforestation coupled with over harvesting all together have resulted in dwindling population of important medicinal plants around the world and Origanum different species were not an exception [12]. Therefore, Finding solutions for problems facing such rare plants is a must. Each medicinal plant harbors a distinctive microbiome due to their unique and structurally divergent bioactive secondary metabolites that are most likely responsible for the high specificity of the associated microorganisms [13]. Up to our knowledge, there is no report on Origanum syriacum spp. sinaicum associated bacteria, therefore this study aims to isolate and characterize wild and cultivated oregano associated bacteria to assess their PGP traits. The outcome of this study will form the basis for the selection of a suitable PGP bacteria that would be used later as a bio-fertilizer to facilitate oregano domestication and to improve its growth and metabolism. 


\section{Materials and Methods}

Collection of the plant materials and isolation of plant growth promoting bacteria from different niches:

Origanum syriacum spp. sinaicum samples were collected from Saint Katherine Protectorate, the wild environment of this plant in Egypt. From Wadi Garagnia, four plant samples were carefully removed with roots from different land forms and at different heights up to 2000 meters above the sea level. Nine additional aerial parts were obtained from Wadi Garagnia and Wadi Meserdy. Additionally, three other cultivated plants were collected from Medicinal Plants Conservation Project in Saint Katherine. All samples were collected in sterile polythene bags and brought to the laboratory for the isolation of endophytic and rhizospheric bacteria within 24 $\mathrm{h}$ after collection.

\section{- Isolation of rhizospheric and endophytic bacteria:}

To isolate rhizospheric bacteria, wild oregano samples were uprooted along with soil adhering to the root. About $5 \mathrm{~g}$ of the rhizospheric soil, which collected by shaking in sterilized bags, were transferred to $50 \mathrm{ml}$ sterilized tap water and shaken for $15 \mathrm{~min}$. at room temperature. Serial dilutions were prepared as described previously [14]. For streaking, a loop of each dilution was streaked on Luria Broth (LB) plates. The plates were incubated at $30^{\circ} \mathrm{C}$ for $24 \mathrm{~h}$. Colonies with different morphology were picked up and purified on LB plates by repeated streaking.

To analyze endophytic bacteria, the collected oregano samples were separated into root and aerial parts then the following procedures were done separately. The obtained root samples were washed with sterilized dist. water then, the root parts were subjected to surface sterilization by $0.2 \mathrm{M} \mathrm{HgCl}_{2}$ in $50 \%$ ethanol for 4 minutes and finally additional washing by sterilized dist. water was performed. Under aseptic conditions, the sterilized roots were cut into small segments, dried over sterilized filter paper, and finally spread over nutrient agar plates and incubated at $30^{\circ} \mathrm{C}$ for $24 \mathrm{~h}$ in order to confirm the success of surface sterilization process [15-17].

The surface sterilization of the aerial parts was performed by $70 \%$ ethanol for 1 minute and then $3 \%$ sodium hypochloride for 6 minutes [3]. The success of the surface sterilization was also confirmed as mentioned previously.

In order to isolate the endophytic bacteria, the aerial and root parts were macerated separately in a sterilized $0.8 \% \mathrm{KCl}$ solution by using a sterilized mortar and pestle under aseptic conditions. Then the serial dilution method was performed and the samples were streaked on LB plates and incubated at $30^{\circ} \mathrm{C}$ for $24 \mathrm{~h}$. The colonies with different morphology were further purified and kept at glycerol stocks for further experiments.

\section{Selection of the best plant growth promoting (PGP) isolates:}

Whether rhizospheric or endophytic, the obtained isolates were further subjected to a set of experiments in order to select the PGP bacteria among them. These experiments aimed to test the production of gibberellic acid and nitrogen fixation activity [4-6].

\section{- Gibberellic acid production test:}

$25 \mathrm{ml}$ of LB media was inoculated with each bacterial isolate and the cultures were incubated at $30^{\circ} \mathrm{C}$ for 3 days in dark. After centrifugation, $5 \mathrm{ml}$ of the culture supernatant was adjusted to $\mathrm{pH} 2.8$ by $0.1 \mathrm{~N} \mathrm{HCl}$ and then extracted 3 times by equal volume of ethyl acetate in a separating funnel and the resulting ethyl acetate fractions were collected. The ethyl acetate fraction was then passed through sodium sulphate anhydrous. Then $1 \mathrm{ml}$ Folin reagent was added to $1 \mathrm{ml}$ of the treated ethyl acetate fraction in addition to $1 \mathrm{ml}$ conc. $\mathrm{HCl}$ and $3 \mathrm{ml}$ of distilled water in a boiling water bath for $5 \mathrm{~min}$. and the absorbance was measured at $750 \mathrm{~nm}$ [18]. The isolates produced the highest amounts of GA were passed to the next selection step; the nitrogenase activity test.

\section{- Nitrogenase activity assay:}

Nitrogenase (EC 1.18.6.1) activity was assayed for the selected bacterial isolates according to acetylene reduction method described by [19] and modified by [20]. At first, one colony of each bacterial isolate was inoculated in Watanabi broth, a specific medium for the selection of nitrogen-fixing bacteria [21]. Subsequently, $20 \mathrm{ml}$ of fresh Watanabi semi-solid medium was inoculated with $1 \mathrm{ml}$ of the culture of the tested isolates. The incubation was carried out at $30^{\circ} \mathrm{C}$ for $24 \mathrm{~h}$ and sterilized sob seal was used to prevent gas leakage. $10 \%$ of the bottle`s air was then replaced by acetylene gas and then after four hours, the gas phase of the bottles was mixed thoroughly and $0.5 \mathrm{ml}$ gas sample was taken for ethylene measurement using Gas Chromatography (model HP6890 GC). Serial dilutions of pure ethylene were used in constructing the standard curve. Whether endophytic or rhizospheric, the isolates that gave the highest nitrogenase activity were nominated as potential plant growth promoting bacteria.

\section{Morphological characteristic and molecular identification of the selected isolates:}


The selected isolates were described morphologically on nutrient agar plates. Furthermore, Gram staining, motility, pigment production and catalase activity were also determined [22].

The Bacterial genomic DNA of each strain was extracted and used as a template for PCR amplification of the 16S rRNA gene using forward primer 5'ACTCCTACGGGAGGCAGCAG, and a reverse primer 5'ATTACCGCGGCTGCTGG. The PCR product was purified and sequenced. The generated sequences were analyzed by Finch TV software and the phylogenetic tree was generated via Seaview software using the closest published type strains sequences.

Testing for further plant growth promoting activities:

In order to confirm the potentiality of the finally selected isolates as plant growth promoting bacteria, the isolates were subjected to the following tests;

\section{- Production of phytohormones:}

The selected bacterial isolates were inoculated in $25 \mathrm{ml}$ Watanabi media supplied with $5 \mathrm{mM}$ tryptophan and incubated for 2 days in dark conditions at $30^{\circ} \mathrm{C}$. After centrifugation, the $\mathrm{pH}$ of the culture supernatant was shifted to 2.8 then the samples were extracted with ethyl acetate [23-25].

The phytohormones in the ethyl acetate fractions were separated by thin layer chromatography using a solvent system of isopropanol/ammonia/distilled water (10:1:1 w). IAA, $\mathrm{GA}_{3}$, and $\mathrm{ABA}$ bands were detected under UV according to the standards of all of them. Bands detected were scraped and dissolved in methanol and analyzed by High performance liquid chromatography using a reverse phase Supelcosil LC-18 column $(25 \mathrm{~cm} \times$ 4,6 mm) by Cecil 1100 Series Liquid Chromatograph. Samples were analyzed under isocratic conditions with $35 \%$ methanol (in 1\% acetic acid) for 1AA, 30\% methanol (adjusted to $\mathrm{PH} 3.0$ with $0.1 \mathrm{M} \mathrm{H}_{3} \mathrm{PO}_{4}$ ) for $\mathrm{GA}_{3}$ and $55 \%$ methanol (in $0.1 \mathrm{M}$ acetic acid) for ABA. Wave lengths in the UV detector were 280, 208 and $265 \mathrm{~nm}$ for IAA, GA3 and ABA respectively. The total run time for separations was approximately $15 \mathrm{~min}$ at a flow rate of $1 \mathrm{ml} / \mathrm{min}$.

\section{- Ammonia production:}

For testing ammonia production, the isolates were raised in $10 \mathrm{ml}$ of peptone water medium (containing: $10 \mathrm{~g}$ peptone, $5 \mathrm{~g} \mathrm{NaCl}$ in one liter and then was adjusted to $\mathrm{pH} 7.2$ and incubated at $30^{\circ} \mathrm{C}$ for 4 days. One $\mathrm{ml}$ of culture was added to a test tube containing one $\mathrm{ml}$ of Nesseler's reagent. Development of the yellow to brown color indicates the production of ammonia [26].

\section{- Phosphate solubilization:}

Phosphate solubilization was assayed by using Pikovaskaya's medium [27]. The plates were inoculated with $10 \mu \mathrm{l}$ of the fresh isolate cultures spotted on the four quarters of the plate and incubated at $30^{\circ} \mathrm{C}$ for 7 days. The plates routinely checked for formation of transparent haloes around the bacterial growth.

\section{- Hydrogen cyanide $(\mathrm{HCN})$ production:}

The fresh cultures of the selected isolates were streaked on King's B medium supplied with $4.4 \mathrm{~g} / \mathrm{l}$ glycine. Whatman no.1 filter paper discs soaked in $0.5 \%$ picric acid (in $2 \%$ sodium carbonate) were placed in the lid of the Petri dishes in order to detect the production of HCN. The plates were tightly sealed with parafilm and incubated at $30^{\circ} \mathrm{C}$ for 4 days till the development of deep orange colour [28].

\section{- 1-Aminocyclopropane-1-carboxylate deaminase assay:}

The activity of 1-aminocyclopropane-1-carboxylate deaminase (ACC-deaminse) was determined according to the previously described method [29]. The selected isolates were inoculated in $100 \mathrm{ml}$ of Dobereiner medium (nitrogen free based medium) [30]. The cultures were incubated at $30^{\circ} \mathrm{C}$ for 2 days to get rid of any nitrogen traces. $3 \mathrm{ml}$ of DF salt minimal medium was supplemented with ACC solution (as the sole nitrogen source) to $3 \mathrm{mM}$ final concentration [31]. This DF-ACC medium was inoculated with $200 \mu \mathrm{l}$ of Dobereiner culture and incubated for $24 \mathrm{~h}$ at $30^{\circ} \mathrm{C}$. After centrifugation, $1 \mathrm{ml}$ of the supernatant was mixed with ninhydrine reagent. The tubes were closed tightly then put in a boiling water bath. The absorbance of samples color was measured at $570 \mathrm{~nm}$.

\section{Results}

Isolation and selection of Origanum syriacum ssp. sinaicum associated growth promoting bacteria: Several rhizospheric as well as endophytic isolates were obtained from both wild and cultivated plants. To discriminate PGPB from others, all the isolates were tested for the production of gibberellic acid colourimetrically. The bacterial isolates that gave the highest amount of GA, 25 isolates, were passed for the next selection step; the nitrogenase activity which led to the final selection of 4 bacterial isolates. Among them, 
the isolates B2 and B3 were originally isolated as endophytes from cultivated (root) and wild (shoot) of oregano respectively. The other two B4 and B5 were obtained from cultivated and wild oregano rhizosphere respectively. Beside these isolates, an active reference stain B1 (Bacillus polymyxa), known for its PGP characteristics, has been used as a positive control for the proceeding experiments [32]. The morphological characteristics of these isolates, in addition to the reference strain, were observed on nutrient agar media as indicated in table 1 . The $16 \mathrm{~S}$ rRNA sequence analysis showed a very high sequence similarity between B2 and B5 isolates and the members of genus Serratia (figure 1) while B3 and B4 showed the identity to Bacillus sp. (figure 2). The isolates B2 and B5 were further given the names Serratia SK3 and Serratia SK1a respectively and B3 and B4 were given the names Bacillus SK1 and Bacillus SK2 respectively. The partial sequence obtained for 16s rRNA genes of all the identified organisms were submitted to the gene bank under the accession numbers KU379654, KU379656, KU379655, KU379657 for Bacillus sp. SK1, Bacillus sp. SK2, Serratia sp. SK1a and Serratia sp. SK3 respectively.

\section{Further plant growth promotion characteristics}

The HPLC analysis performed to detect the production of phytohormones by the isolates under investigation showed that, all of them did not produce a detectable level of IAA and ABA, however, all the isolates produce $\mathrm{GA}_{3}$. The highest producer was B5 Serratia SK1a, while the lowest production was detected by $\mathbf{B} 4$ Bacillus SK2 compared to the reference strain B1 Bacillus polymxa (table 2).

All the selected isolates show the ability to produce ammonia. Ammonia production was significantly higher for B2 Serratia SK3 and B4 Bacillus SK2 than other isolates and the reference strain (table 2).

Phosphate solubilization has been indicated for all the selected isolates as indicated in table 2. The isolates B2 Serratia SK3 and B5 Serratia SK1a showed the highest phosphate Solubilization capacity compared to the reference strain as indicated by the wider area of the clear zone.

Hydrogen cyanide (HCN) production was indicated for B2 Serratia SK3 ,however, the other isolates, including the reference strain, did not produce $\mathrm{HCN}$ under the same experimental conditions.

All the tested isolates including the reference strain showed ACC-deaminase activity as shown in table 2. However, the higher activity was recorded to the isolates B3 Bacillus SK1, and B4 Bacillus SK2 compared to the reference strain.

\section{Discussion}

Due to the significance of Origanum syriacum spp. sinaicum as a medicinal plant, the decision was taken to perform this study aiming to isolate its naturally associated bacteria and to evaluate their growth promoting criteria, a step that might enable their use as bio-inoculants to improve the plant growth and metabolism. Among 268 isolates originally obtained, it became experimentally evident that, the finally selected isolates; B3 Bacillus SK1 ,B4 Bacillus SK2 ,B2 Serratia SK3 and B5 Serratia SK1a showed the highest capacity to produce GA3 and the highest nitrogenase activity.

Although the identified bacteria were not previously recorded as an associate of Origanum syriacum ssp. sinaicum whether as rhizospheric or endophytic bacteria, several studies showed the association of Serratia sp. [33, 34] and Bacillus [35], [36, 37] both as rhizosphere and/or endophyte with other plants.

The ability to produce $\mathrm{GA}_{3}$ might be a key tool that assists the obtained Serratia and Bacillus to invade the plant tissue and rhizospere region as valuable endophytes. This explanation has been indicated previously by various authors [38, 39]. The production of $\mathrm{GA}_{3}$ has been reported for several species such as Bacillus licheniformis and Bacillus pumilus [40]. Moreover several Serratia species has been figured as gibberellic acid producer [41].

An additional essential role that could be played by the PGPB is the ability to fix atmospheric nitrogen [42]. The isolated strains in this study have the ability to fix nitrogen as indicated by the results of nitrogenase assay and supported by measuring ammonia production (table 2). Earlier studies reported the ability of Serratia $s p$. isolated from the rice to fix nitrogen [43] and reported the same ability to an isolated Bacillus sp. [44]. In addition to its direct influence on plant growth and metabolism, ammonia production might indirectly influence the plant growth [45] by shifting the $\mathrm{pH}$ to alkaline condition leading to growth suppression of certain fungi and nitrobacteria [46].

Phosphate solubilization is another help that could be provided by PGPB to the plant to support its growth and metabolism. Phosphate-solubilizing bacteria are able to solubilize phosphate inorganic compounds such as tricalcium phosphate by the production of organic acids [47]. In agreement with previous studies, the obtained bacterial isolates showed the ability to solubilize phosphate. High phosphate solubilization activity by Serratia sp. was reported by previous studies [48-50] that supported observation that gave Serratia isolates higher grade of phosphate solubilization compared with Bacillus isolates. The isolation of B2 Serratia SK3 as endophyte from cultivated root and B5 Serratia SK1a from the rhizospere of the wild oregano supports that it might be associated with the plant to enhance phosphate uptake. 
The ability of B2 Serattia SK3 to produce HCN has been reported previously for other Serattia species [51] and it add to us another benefit for its association with oregano as the production of HCN might protect plant from various biotic stresses [52].

The ability to metabolize 1-aminocyclopropane-1-carboxylate (ACC), the precursor of ethylene, by ACC-deaminase activity is another potential role of the obtained isolates that might be used to reduce the production of ethylene [53, 54]. Both Bacillus [35] and Serratia [55] different species showed ACC-deaminase activity in other previous studies.

In conclusion, this study spot the light on the plant growth promoting bacteria associated with Origanum syriacum ssp. sinaicum and their abilities in various metabolic processes. The desired characters founded in these isolates open the door for their use later as bio-inoculants that would improve oregano growth and metabolism.

\section{References}

[1]. Lucy, M., E. Reed, and B.R. Glick, Applications of free living plant growth-promoting rhizobacteria. Antonie van Leeuwenhoek, 2004. 86(1): p. 1-25

[2]. Chin-A-Woeng, T.F., et al., Phenazine-1-carboxamide production in the biocontrol strain Pseudomonas chlororaphis PCL1391 is regulated by multiple factors secreted into the growth medium. Molecular plant-microbe interactions, 2001. 14(8): p. 969-979.

[3]. Boyle, C., et al., Endophyte-host interactions. III. Local vs. systemic colonization. Symbiosis, 2001. 31(4): p. 259-281

[4]. Dubeikovsky, A., et al., Growth promotion of blackcurrant softwood cuttings by recombinant strain Pseudomonas fluorescens BSP53a synthesizing an increased amount of indole-3-acetic acid. Soil biology and Biochemistry, 1993. 25(9): p. 1277-1281.

[5]. Blaha, D., et al., Phylogeny of the 1-aminocyclopropane-1-carboxylic acid deaminase-encoding gene acdS in phytobeneficial and pathogenic Proteobacteria and relation with strain biogeography. FEMS Microbiology Ecology, 2006. 56(3): p. 455-470.

[6]. Belimov, A., et al., Pseudomonas brassicacearum strain Am3 containing 1-aminocyclopropane-1-carboxylate deaminase can show both pathogenic and growth-promoting properties in its interaction with tomato. Journal of Experimental Botany, 2007. 58(6): p. 1485-1495.

[7]. Enebak, S. and W. Carey, Evidence for induced systemic protection to fusiform rust in loblolly pine by plant growth-promoting rhizobacteria. Plant Disease, 2000. 84(3): p. 306-308.

[8]. Babalola, O.O., et al., Amplification of 1-amino-cyclopropane-1-carboxylic (ACC) deaminase from plant growth promoting rhizobacteria in Striga-infested soil. African Journal of Biotechnology, 2003. 2(6): p. 157-160.

[9]. Boulos, L., Flora of Egypt: Volume Three (Verbinaceae-Compositae). Al-Hadara Publishing, Cairo, Egypt, 2002.373.

[10]. Radford, E.A., G. Catullo, and B. de Montmollin, Important plant areas of the South and East Mediterranean region: priority sites for conservation. 2011: International Union for Conservation of Nature.

[11]. Tackholm, V., Students' Flora of Egypt. 1974, Cairo,Egypt: Cairo University Press. p. pp 888.

[12]. Padulosi, S., Oregano: Proceedings of the IPGRI International Workshop on Oregano, 8-12 May 1996, CIHEAM, Valenzano (Bari), Italy. Vol. 14. 1997: Bioversity International.

[13]. Qi, X., et al., Rhizosphere and non-rhizosphere bacterial community composition of the wild medicinal plant Rumex patientia. World Journal of Microbiology and Biotechnology, 2012. 28(5): p. 2257-2265.

[14]. Alexander, M. and F.E. Clark, Nitrifying bacteria. Methods of soil analysis. Part 2. Chemical and microbiological properties, 1965(methodsofsoilanb): p. 1477-1483.

[15]. Pleban, S., F. Ingel, and I. Chet, Control ofRhizoctonia solani andSclerotium rolfsii in the greenhouse using endophyticBacillus spp. European Journal of Plant Pathology, 1995. 101(6): p. 665-672.

[16]. Shishido, M., B. Loeb, and C. Chanway, External and internal root colonization of lodgepole pine seedlings by two growthpromoting Bacillus strains originated from different root microsites. Canadian Journal of Microbiology, 1995. 41(8): p. 707-713.

[17]. Schulz, B., et al., Endophyte-host interactions. II. Defining symbiosis of the endophyte-host interaction. Symbiosis, Philadelphia, Pa.(USA), 1998.

[18]. Udagwa and Kinoshita, A colorimetric determination of gibberellic acid Journal of Agricultural Chemistry Society Japan, 1961. 35: p. 219-223.

[19]. Hardy, R., R. Burns, and R.D. Holsten, Applications of the acetylene-ethylene assay for measurement of nitrogen fixation. Soil Biology and Biochemistry, 1973. 5(1): p. 47-81.

[20]. Somasegaran, P. and H. Hoben, Methods in legume-Rhizobium technology/Hawaii inst. of tropical agriculture and human resources. 1985 .

[21]. Watanabe, I. and W.L. Barraquio, Low levels of fixed nitrogen required for isolation of free-living N2-fixing organisms from rice roots. 1979.

[22]. Verma, P.S.B., Handbook of Microbiology. First edition. ed. 2004: CBS Publishers \& Distributors Pvt. Ltd.

[23]. Unyayar, S., S. Topcuoglu, and A. Unyayar, A modified method for extraction and identification of indole-3-acetic acid (IAA), gibberellic acid (GA3), abscisic acid (ABA) and zeatin produced by Phanerochaete chrysosporium ME446. Bulg J Plant Physiol, 1996. 22(3-4): p. 105-110

[24]. Baydar, H. and S. Ulger, Correlations between changes in the amount of endogenous phytohormones and flowering in the safflower (Carthamus tinctorius L.). Turk. J. Biol, 1998. 22(4): p. 421-425.

[25]. Karadeniz, A., S. Topcuoğlu, and S. Inan, Auxin, gibberellin, cytokinin and abscisic acid production in some bacteria. World Journal of Microbiology and Biotechnology, 2006. 22(10): p. 1061-1064.

[26]. Dye, D., The inadequacy of the usual determinative tests for the identification of Xanthomonas spp. New Zealand Journal of Science, 1962. 5(4): p. 393-416.

[27]. Sundara-Rao, W. and M. Sinha, Phosphate dissolving microorganisms in the soil and rhizosphere. Indian J. Agric. Sci, 1963. 33(4): p. 272-278.

[28]. Bakker, A.W. and B. Schippers, Microbial cyanide production in the rhizosphere in relation to potato yield reduction and Pseudomonas spp-mediated plant growth-stimulation. Soil Biology and Biochemistry, 1987. 19(4): p. 451-457.

[29]. Li, Z., et al., A colorimetric assay of 1-aminocyclopropane-1-carboxylate (ACC) based on ninhydrin reaction for rapid screening of bacteria containing ACC deaminase. Letters in applied microbiology, 2011. 53(2): p. 178-185.

[30]. Döbereiner, J. and J. Day. Associative symbioses in tropical grasses: characterization of microorganisms and dinitrogen-fixing sites. in Proceedings of the 1st international symposium on nitrogen fixation. 1976. Washington State University Press Pullman. 
[31]. Dworkin, M. and J. Foster, Experiments with some microorganisms which utilize ethane and hydrogen. Journal of bacteriology, 1958. 75(5): p. 592.

[32]. Omar, M., Selection of nitrogen fixing bacteria from Egyptian Soils and their inoculation for improving rice yield. Ph. D. Thesis Nancy Univ., France, 1987.

[33]. Lopez-Fuentes, E., et al., Bacterial community in the roots and rhizosphere of Hypericum silenoides Juss. 1804. African Journal of Microbiology Research, 2012. 6(11): p. 2704-2711.

[34]. Tamilarasi, S., et al., Diversity of root associated microorganisms of selected medicinal plants and influence of rhizomicroorganisms on the antimicrobial property of Coriandrum sativum. Journal of Environmental Biology, 2008.

[35]. Nongkhla, F.M.W. and S. Joshi, Epiphytic and endophytic bacteria that promote growth of ethnomedicinal plants in the subtropical forests of Meghalaya, India. International Journal of Tropical Biology and Conservation, 2014. 62(4): p. 1295-1308.

[36]. Köberl, M., et al., The microbiome of medicinal plants: diversity and importance for plant growth, quality and health. Frontiers in microbiology, 2013. 4

[37]. El-Deeb, B., K. Fayez, and Y. Gherbawy, Isolation and characterization of endophytic bacteria from Plectranthus tenuiflorus medicinal plant in Saudi Arabia desert and their antimicrobial activities. Journal of Plant Interactions, 2013. 8(1): p. $56-64$.

[38]. Goodman, R.N., Z. Király, and K.R. Wood, The biochemistry and physiology of plant disease. 1986: University of Missouri Press

[39]. Dobbelaere, S., J. Vanderleyden, and Y. Okon, Plant growth-promoting effects of diazotrophs in the rhizosphere. Critical Reviews in Plant Sciences, 2003. 22(2): p. 107-149.

[40]. Gutiérrez-Mañero, F.J., et al., The plant-growth-promoting rhizobacteria Bacillus pumilus and Bacillus licheniformis produce high amounts of physiologically active gibberellins. Physiologia Plantarum, 2001. 111(2): p. 206-211.

[41]. UmaMaheswari, T., et al., Studies on phytohormone producing ability of indigenous endophytic bacteria isolated from tropical legume crops. Int. J. Curr. Microbiol. App. Sci, 2013. 2(6): p. 127-136.

[42]. Vessey, J.K., Plant growth promoting rhizobacteria as biofertilizers. Plant and soil, 2003. 255(2): p. 571-586

[43]. Sandhiya, G., et al., Endophytic colonization and in planta nitrogen fixation by a diazotrophic Serratia sp. in rice. Indian journal of experimental biology, 2005. 43(9): p. 802.

[44]. Beneduzi, A., et al., Evaluation of genetic diversity and plant growth promoting activities of nitrogen-fixing bacilli isolated from rice fields in South Brazil. Applied Soil Ecology, 2008. 39(3): p. 311-320.

[45]. Kumar, A., et al., Isolation, screening and characterization of bacteria from rhizospheric soils for different plant growth promotion (PGP) activities: an in vitro study. Recent Research in Science and Technology, 2012. 4(1).

[46]. Martin, A., 'Soil Microbiology', sec. Edition 1982, : John Willey \& Sons.

[47]. Chen, Y., et al., Phosphate solubilizing bacteria from subtropical soil and their tricalcium phosphate solubilizing abilities. Applied soil ecology, 2006. 34(1): p. 33-41

[48]. Hameeda, B., et al., Effect of carbon substrates on rock phosphate solubilization by bacteria from composts and macrofauna. Current microbiology, 2006. 53(4): p. 298-302.

[49]. Selvakumar, G., et al., Cold tolerance and plant growth promotion potential of Serratia marcescens strain SRM (MTCC 8708) isolated from flowers of summer squash (Cucurbita pepo). Letters in applied microbiology, 2008. 46(2): p. 171-175.

[50]. Perez, E., et al., Isolation and characterization of mineral phosphate-solubilizing bacteria naturally colonizing a limonitic crust in the south-eastern Venezuelan region. Soil Biology and Biochemistry, 2007. 39(11): p. 2905-2914.

[51]. Gujral, M.S., et al., Colonization and plant growth promotion of Sorghum seedlings by endorhizospheric Serratia sp. Acta Biologica Indica, 2013. 2(1): p. 121-124.

[52]. Glick, B. and J. Pasternak, Plant growth promoting bacteria. Molecular biotechnology principles and applications of recombinant DNA, 2003. 3: p. 436-54.

[53]. Klee, H.J., et al., Control of ethylene synthesis by expression of a bacterial enzyme in transgenic tomato plants. The Plant Cell, 1991. 3(11): p. 1187-1193.

[54]. Glick, B.R., D.M. Penrose, and J. Li, A model for the lowering of plant ethylene concentrations by plant growth-promoting bacteria. Journal of Theoretical Biology, 1998. 190(1): p. 63-68.

[55]. Zahir, Z.A., et al., Comparative effectiveness of Pseudomonas and Serratia sp. containing ACC-deaminase for coinoculation with Rhizobium leguminosarum to improve growth, nodulation, and yield of lentil. Biology and Fertility of Soils, 2011. 47(4): p. 457465 . 
Table 1: Morphological and biochemical characters of the selected PGPBs.

\begin{tabular}{|c|c|c|c|c|c|}
\hline Isolate/Phenotypic of colony & B1 & B2 & B3 & B4 & B5 \\
\hline \multicolumn{6}{|l|}{ On Solid Agar } \\
\hline Colony form & Circular & Circular & Circular & Circular & Irregular \\
\hline elevation & Convex & Umbonate & Raised & Flat & Raised \\
\hline margin & Entire & Entire & Dentate & Entire & Lobate \\
\hline surface & Smooth & Smooth & Smooth & Smooth & Smooth \\
\hline color & Off-white & Off-white & White & Off-white & White \\
\hline size & Moderate & Moderate & Punctiform & Big & Punctiform \\
\hline consistency & Butyrous & Butyrous & Butyrous & Butyrous & Butyrous \\
\hline Optical Density & Translucent & Translucent & Opaque & Translucent & Opaque \\
\hline \multicolumn{6}{|l|}{ On nutrient broth } \\
\hline Amount of growth & Abundant & Abundant & Moderate & Moderate & Abundant \\
\hline Surface Growth & -ve & -ve & -ve & -ve & -ve \\
\hline Sub-surface growth (Dob.semiliquid) & $+++\mathrm{ve}$ & $++\mathrm{ve}$ & $+\mathrm{ve}$ & -ve & -ve \\
\hline Sediment growth & -ve & -ve & -ve & $+\mathrm{ve}$ & $+\mathrm{ve}$ \\
\hline \multicolumn{6}{|l|}{ On nutrient agar -slant } \\
\hline Amount of growth & Abundant & Abundant & Abundant & Abundant & Abundant \\
\hline Form & Distributed & Distributed & Branched & Beady & Distributed \\
\hline Pigmentation & -ve & -ve & -ve & -ve & -ve \\
\hline Colour & Off-White & Off-White & Off-White & Off-White & Off-White \\
\hline Opacity & Translucent & Translucent & Opaque & Opaque & Translucent \\
\hline Organism identified & Bacillus sp. & Serratia sp. & Bacillus sp. & Bacillus sp. & Serratia sp. \\
\hline
\end{tabular}

B1: Bacillus polymxa, B2: Serratia SK3, B3: Bacillus SK1, B4: Bacillus SK2 ,B5 Serratia SK1a.+ve=positive,-ve=negative.

Table 2: Plant growth promoting traits of (B1,B2, B3, B4 and B5).

\begin{tabular}{|c|c|c|c|c|c|c|c|c|}
\hline Traits & $\mathbf{H C N}$ & $\begin{array}{c}\text { Phosphate } \\
\text { Solubilization }\end{array}$ & $\begin{array}{l}\text { Ammonia } \\
\text { Production }\end{array}$ & $\begin{array}{l}\text { ACC } \\
\text { deaminase }\end{array}$ & $\begin{array}{l}\mathrm{N}_{2} \text { ase (nmoles } \\
\mathrm{C}_{2} \mathrm{H}_{4} / \mathrm{ml} / \mathrm{h} \text { ) }\end{array}$ & IAA & $\mathbf{G A}_{3}$ & ABA \\
\hline B1 & - & + & + & + & $\begin{array}{l}8.9 \\
\pm 1.2^{\mathrm{b}} \\
\end{array}$ & n.a. & +++ & n.a. \\
\hline B2 & ++ & +++ & ++ & + & $\begin{array}{l}17.87 \\
\pm 5.6^{\mathrm{a}} \\
\end{array}$ & n.a. & ++ & n.a. \\
\hline B3 & - & + & + & ++ & $\begin{array}{l}9.5 \\
\pm 3.4^{\mathrm{b}}\end{array}$ & n.a. & ++ & n.a. \\
\hline B4 & - & ++ & ++ & ++ & $\begin{array}{l}12.6 \\
\pm 1.7^{\mathrm{ab}}\end{array}$ & n.a. & + & n.a. \\
\hline B5 & - & +++ & + & + & $\begin{array}{l}11.75 \\
\pm 2.2^{\mathrm{ab}}\end{array}$ & n.a. & ++++ & n.a. \\
\hline
\end{tabular}

Numerical values are mean \pm SD. Treatments with identical letters are not significant at $\mathrm{P} \leq 0.05$. $\mathrm{HCN}=$ hydrogen cyanide; $\mathrm{P}=$ phosphorous; $\mathrm{IAA}=$ indole acetic acid; GA3= gibberellic acid; $\mathrm{ABA}=$ abscisic acid ;n.a=not attained;+ trait is present; + low; ++ moderate ;+++high,++++very high B1: Bacillus polymxa, B2: Serratia SK3, B3: Bacillus SK1,B4: Bacillus SK2, B5: Serratia SK1a,+ve=positive,-ve=negative. 


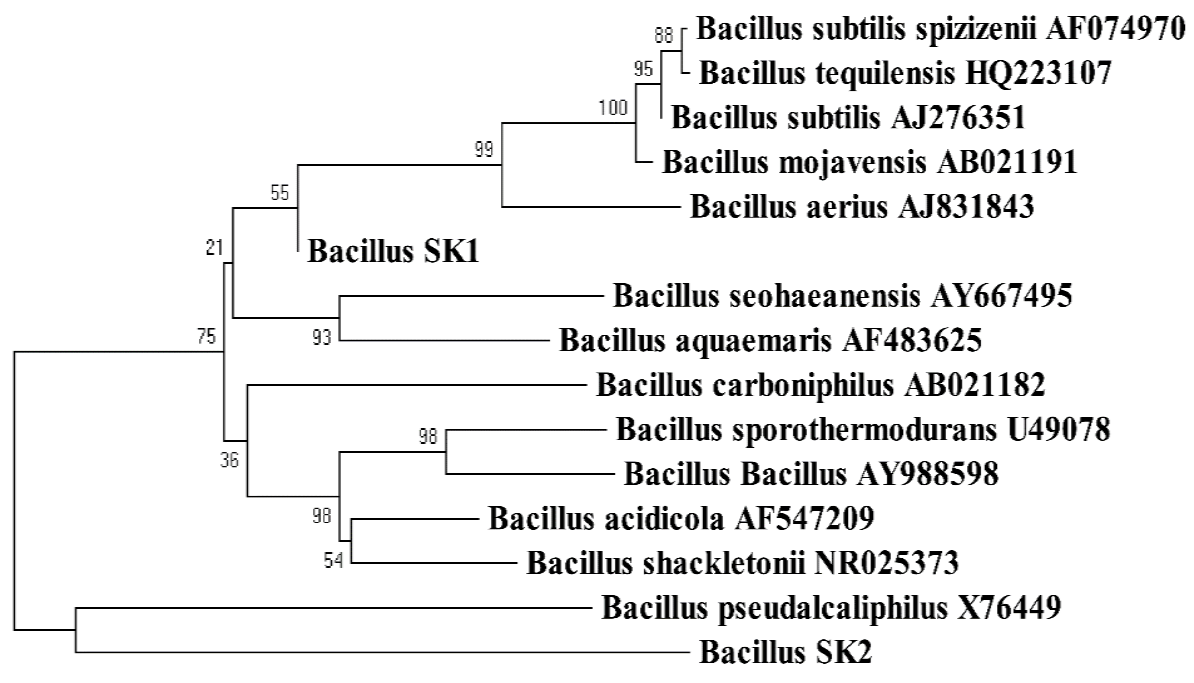

$\vdash_{0.005}$

Figure 1: The phylogenetic tree that indicates the position of the Bacillus isolates among other Bacillus type strains.

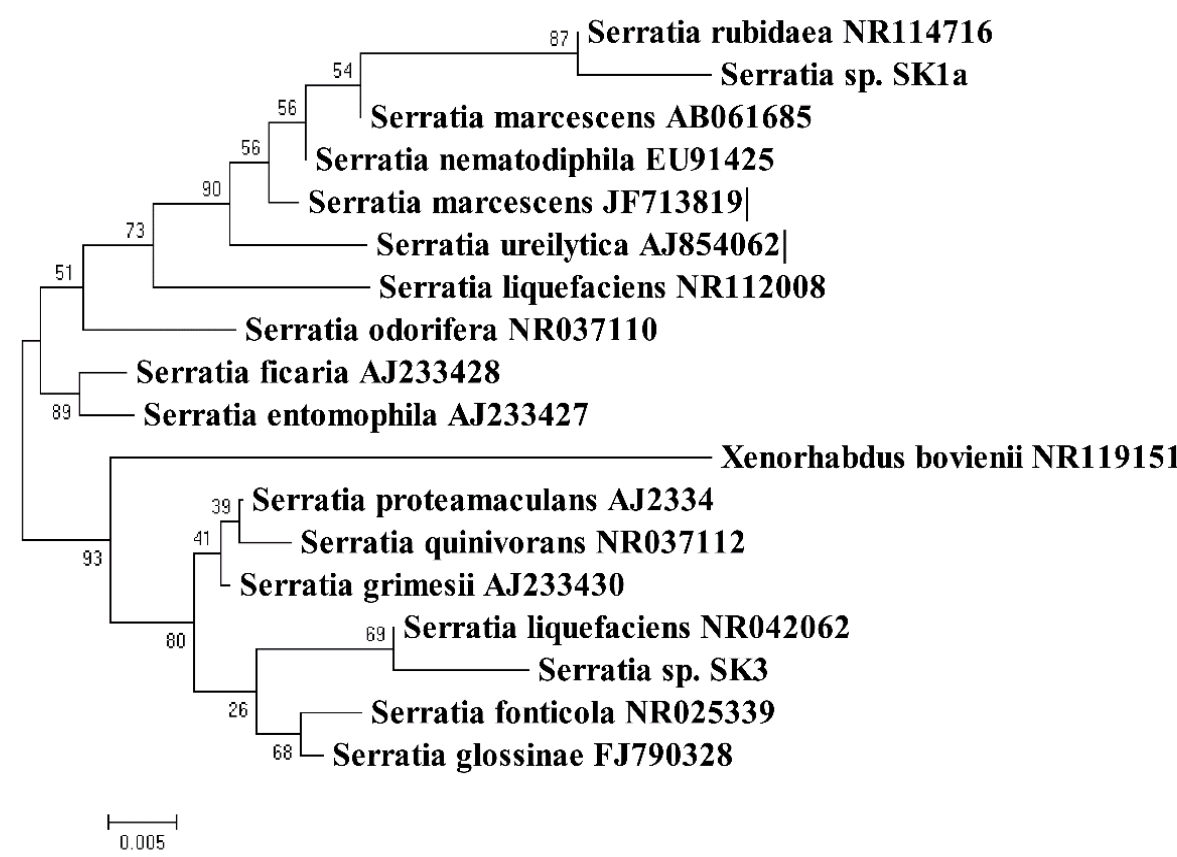

Figure 2: The phylogenetic tree that indicates the position of the Serratia isolates among other Serratia type strains. 